\title{
Simulasi Model Diskrit Respons Sistem Imun pada Penyebaran Tumor Otak dengan Metode Beda Hingga Standar
}

\author{
Icha Zakiyya Nafisah Roza1, Usman Pagalay²*, Heni Widayani \\ Program Studi Matematika, Fakultas Sains dan Teknologi Universitas Islam Negeri Maulana Malik Ibrahim \\ Malang, Indonesia
}

Email: inafisahroza@gmail.com, usmanpagalay@yahoo.co.id*, heniwidayani@mat.uin-malang.ac.id

\begin{abstract}
ABSTRAK
Penelitian ini membahas tentang simulasi model diskrit respons sistem imun pada penyebaran tumor otak menggunakan metode beda hingga standar. Model tersebut akan didiskritisasi dengan menggunakan metode beda hingga standar. Metode beda hingga standar atau metode Euler merupakan metode yang diturunkan dari deret Taylor. Model pada penelitian ini terdapat lima variabel yaitu, glioma (G), makrofag (M), sel T CD8 ${ }^{+}(C)$, TGF- $\beta\left(\mathrm{T}_{\beta}\right)$, dan IFN- $\gamma\left(\mathrm{I}_{\gamma}\right)$. Berdasarkan hasil analisis diketahui bahwa model diskrit penyebaran tumor otak dengan respon sistem imun memiliki jenis kestabilan model diskrit sama dengan model kontinunya dan memiliki dua titik kesetimbangan, yaitu kesetimbangan bebas penyakit dan kesetimbangan endemik. Titik kesetimbangan bebas penyakit dan endemik bersifat stabil asimtotik apabila memenuhi kriteria kestabilan Schur-Cohn. Simulasi numerik dilakukan untuk mengilustrasikan dan menguji hasil analisis yang diperoleh. Hasil simulasi model diskrit diperoleh bahwa model diskrit sama dengan model kontinunya atau stabil saat $0<h \leq 3.34$.
\end{abstract}

Kata kunci: Model Matematika Tumor Otak; Metode Beda Hingga Standar; Analisis Perilaku; Simulasi Model

\begin{abstract}
This study discusses the discrete response system simulation model on the spread of brain tumors using standard finite difference methods. The model will be discretized using the standard finite difference method. The standard finite difference method or Euler's method is a method derived from the Taylor series. The model in this study contained five variables, namely, gliomas (G), macrophages (M), CD8 ${ }^{+}$T cells (C), TGF- $\beta\left(T_{\beta}\right)$, and IFN- $\gamma\left(I_{\gamma}\right)$. Based on the results of the analysis, it is known that the discrete model of brain tumor spread with the immune system has the same type of stability as the continuous model and has two points, namely, diseasefree, and endemic. Disease-free and endemic points are asymptotically stable if they meet the Schur-Cohn stability criteria. Numerical simulations were carried out to illustrate and test the results of the analysis obtained. The result of discrete model simulation shows that the discrete model is the same as the continuous model or is stable at $0<h \leq 3.34$.
\end{abstract}

Keywords: Mathematics Model of Brain Tumor, Standard Finite Difference Method, Behavior Analysis, Model Simulation.

\section{PENDAHULUAN}

Kesehatan merupakan aspek yang penting dalam kehidupan manusia karena menjadi salah satu penunjang aktivitas. Menurut World Health Organization [1] kesehatan adalah suatu keadaan sehat yang utuh secara fisik, mental, dan sosial. Saat ini banyak penyakit bermunculan dari penyakit ringan hingga berbahaya. Salah satu penyakit yang dianggap 
berbahaya adalah tumor [2]. Tumor merupakan penyakit di mana jaringan di dalam tubuh tumbuh secara abnormal. Tumor dapat ditemukan di organ mana pun di dalam tubuh, termasuk dalam sistem saraf manusia. Tumor yang ditemukan dalam sistem saraf pusat disebut sebagai tumor otak [3]. Berbagai teknik prognosis dapat digunakan untuk memprediksi pertumbuhan tumor, salah satunya dengan pendekatan matematis persamaan diferensial atau biasa disebut pemodelan matematika.

Pemodelan matematika dapat menyempurnakan kerangka eksperimen dengan mengidentifikasi pengukuran mana yang diperlukan untuk menguji teori tertentu, serta menguji apakah hipotesis baru dapat diperoleh dari hasil eksperimen [4]. Selain itu, persamaan diferensial telah terbukti menjadi alat yang berguna untuk simulasi evolusi jumlah sel tumor dari waktu ke waktu [5]. Persamaan diferensial adalah persamaan yang memuat satu atau lebih variabel terikat sehubungan dengan satu atau lebih variabel bebas [6]. Sedangkan, persamaan diferensial biasa adalah persamaan diferensial yang melibatkan turunan biasa dan hanya memiliki satu variabel bebas [7]. Persamaan diferensial biasa disebut non linier apabila terdapat variabel terikat yang berpangkat selain satu atau lebih dari satu. Selain itu, terdapat perkalian variabel terikat [6].

Pada jurnal sebelumnya telah dibahas mengenai model matematika tumor otak. Pada penelitian El-Nadi [8] yang membahas tentang model matematika tumor otak untuk mengukur pertumbuhan sel tumor dengan hanya satu persamaan yang melibatkan konsentrasi sel tumor otak, koefisien difusi, dan proliferasi sel tumor. Sel tumor otak tumbuh sangat cepat, sehingga model El-Nadi tersebut dapat digunakan untuk mengetahui waktu yang tepat untuk mengurangi pertumbuhan sel tumor. Kemudian pada penelitian Iarozs [9] yang membahas tentang model matematika tumor otak dengan interaksi neuronglial dan kemoterapi. Pada penelitian tersebut terdapat empat variabel, yaitu sel glial (G), sel glioma (C), sel neuron (N), dan agen kemoterapi (Q). Sel glioma hanya menyerang sel glial dan sel neuron tidak menyerang sel glioma, melainkan berinteraksi dengan sel glial. Agen kemoterapi berperan sebagai predator yang bekerja pada semua sel.

Pada [10], Banerjee mengonstruksi model respons sistem imun pada penyebaran tumor otak sebagai berikut:

$$
\begin{gathered}
\frac{d G}{d t}=r_{1} G\left(1-\frac{G}{G_{\text {max }}}\right)-\left(\frac{1}{T_{\beta}+e_{1}}\right)\left(\alpha_{1} M+\alpha_{2} C_{r}\right)\left(\frac{G}{G+k_{1}}\right) \\
\frac{d M}{d t}=r_{2} M\left(1-\frac{M}{M_{\max }}\right)+a_{1}\left(\frac{I_{\gamma}}{k_{4}+I_{\gamma}}\right)\left(\frac{1}{T_{\beta}+e_{2}}\right)-\alpha_{3}\left(\frac{G}{G+k_{2}}\right) M \\
\frac{d C_{T}}{d t}=\frac{a_{2} G}{k_{5}+T_{\beta}}-\mu_{1} C_{T}-\alpha_{4} \frac{G}{G+k_{3}} C_{T} \\
\frac{d T_{\beta}}{d t}=s_{1}+b_{1} G-\mu_{2} T_{\beta} \\
\frac{d I_{\gamma}}{d t}=b_{2} C_{T}-\mu_{3} I_{\gamma}
\end{gathered}
$$

Model matematika penyebaran tumor otak dengan respons sistem imun pada penelitian ini terdapat interaksi antara sel glioma (tumor) $(G)$ dengan sistem imun yang terdiri dari makrofag $(M)$, sel T CD8 ${ }^{+}(C)$, TGF- $\beta\left(T_{\beta}\right)$ dan IFN- $\gamma\left(I_{\gamma}\right)$. Respon sistem imun terhadap sel glioma diawali oleh makrofag $(M)$ dan sel T $\mathrm{CD}^{+}(C)$ yang diaktivasi oleh IFN$\gamma\left(I_{\gamma}\right)$ sehingga sel glioma $(M)$ mengalami pengurangan populasi [10]. Model [10] akan disimulasikan model diskritnya dengan menggunakan metode beda hingga standar.

Metode beda hingga memiliki konsep dasar, yaitu membagi domain dari penyelesaian persamaan diferensial menjadi sejumlah hingga grid. Kemudian turunan pada masing-masing titik didekati dengan beda hingga [11]. Metode beda hingga standar yang 
sering digunakan untuk melakukan simulasi dari persamaan diferensial, yaitu metode Euler [12]. Melalui pendekatan numerik akan diperoleh solusi dari fungsi kontinu , yang mungkin didapat adalah solusi diskrit dalam bentuk titik-titik di dalam interval [13]. Menurut Hussain dan Liu [14] diskritisasi merupakan proses kuantisasi sifat-sifat kontinu yang berguna untuk mereduksi dan menyederhanakan data, sehingga didapatkan data diskrit yang lebih mudah untuk dipahami, digunakan dan dijelaskan. Solusi diskrit dalam bahasa matematikanya adalah persamaan beda yang merupakan persamaan yang menggambarkan perubahan waktu yang tidak sesaat [15].

Solusi diskrit memberikan banyak manfaat dalam bidang kesehatan yaitu dapat membantu dalam hal pengobatan karena saat diskrit dapat mengetahui waktu tertentu pemberian obat atau perawatan dengan cara mengecek kestabilannya dan menstimulasikannya. Pada model diskrit untuk menganalisis kestabilannya digunakan kriteria kestabilan Schur-Cohn, Solusi dari model diskrit dikatakan stabil asimtotik jika memenuhi syarat pada kriteria kestabilan Schur-Cohn berikut:

$$
A(1)>0 \text {, }
$$

$$
(-1)^{k} A(-1)>0 \text {, }
$$

Matriks $(k-1) \times(k-1)$, merupakan positif innerwise

$$
B_{k-1}^{ \pm}=\left(\begin{array}{ccccc}
1 & 0 & \cdots & & 0 \\
a_{1} & 1 & \cdots & & 0 \\
\vdots & & & & \vdots \\
a_{k-3} & & & & \\
a_{k-2} & a_{k-3} & \cdots & a_{1} & 1
\end{array}\right) \pm\left(\begin{array}{ccccc}
0 & 0 & \cdots & 0 & a_{k} \\
0 & 0 & \cdots & a_{k} & a_{k-1} \\
\vdots & \vdots & & & \vdots \\
0 & a_{k} & & & a_{3} \\
a_{k} & a_{k-1} & \cdots & a_{3} & a_{2}
\end{array}\right)
$$

Matriks $B$ dikatakan positif innerwise jika sub determinan di dalam matriks tersebut bernilai positif [12].

Berdasarkan uraian di atas penulis bermaksud untuk menyimulasikan model diskrit respons sistem imun pada penyebaran respons sistem imun dengan menggunakan metode beda hingga standar. Penelitian ini dimaksudkan untuk mengetahui bentuk diskrit model penyebaran tumor otak dengan respons sistem imun dan untuk mengetahui hasil simulasi dari model diskrit tersebut serta menginterpretasikannya.

\section{METODE}

\section{Langkah-langkah penelitian}

Pada penelitian ini terdapat dua langkah yang pertama, yaitu mendiskritisasi model respons sistem imun pada penyebaran tumor otak pada jurnal karya Banerjee (2015). Diskritisasi tersebut dilakukan dengan menggunakan metode beda hingga standar. Setelah dilakukan diskritisasi akan dianalisis kestabilannya dengan menggunakan kriteria kestabilan Schur-Cohn. Langkah yang kedua, yaitu menyimulasikan dan menginterpretasikan model yang telah didiskritisasi. Simulasi yang dilakukan, yaitu simulasi syarat kestabilan yang didapatkan untuk mencari nilai kestabilan $h$ tertentu dengan bantuan software dan simulasi model diskrit yang mana simulasi tersebut dilakukan dengan menggunakan bantuan software. Selanjutnya, menginterpretasikan hasil dari simulasi tersebut dan membuat kesimpulan.

\section{HASIL DAN PEMBAHASAN}

\section{Model Diskrit Penyebaran Tumor Otak dengan Respons Sistem Imun}


Berdasarkan model (1) pada Banerjee (2015) dengan kondisi :

$$
G(0)=G_{0} \geq 0, M(0)=M_{0} \geq 0, C_{T}(0)=C_{T 0} \geq 0, T_{\beta}=T_{\beta 0} \geq 0, I_{\gamma}=I_{\gamma 0} \geq 0
$$

akan didiskritisasi dengan menggunakan metode beda hingga standar dan model diskrit tersebut akan dianalisis kestabilannya dengan menggunakan kriteria kestabilan SchurCohn.

\section{a. Diskritisasi Model}

Sistem persamaan (1) didiskritisasi menggunakan metode beda hingga standar sebagai berikut:

$$
\begin{aligned}
& \frac{G(t+h)-G(t)}{h}=r_{1} G(t)\left(1-\frac{G(t)}{G_{\max }}\right)-\left(\frac{1}{T_{\beta}(t)+e_{1}}\right)\left(\alpha_{1} M(t)+\alpha_{2} C_{T}(t)\right)\left(\frac{G(t)}{G(t)+k_{1}}\right) \\
& \frac{M(t+h)-M(t)}{h} \\
& =r_{2} M(t)\left(1-\frac{M(t)}{M_{\max }}\right)+a_{1}\left(\frac{I_{\gamma}(t)}{k_{4}+I_{\gamma}(t)}\right)\left(\frac{1}{T_{\beta}(t)+e_{2}}\right) \\
& -\alpha_{3}\left(\frac{G(t)}{G(t)+k_{2}}\right) M(t) \\
& \frac{C_{T}(t+h)-C_{T}(t)}{h}=\frac{a_{2} G(t)}{k_{5}+T_{\beta}(t)}-\mu_{1} C_{T}(t)-\alpha_{4} \frac{G(t)}{G(t)+k_{3}} C_{T}(t) \\
& \frac{T_{\beta}(t+h)-T_{\beta}(t)}{h}=s_{1}+b_{1} G(t)-\mu_{2} T_{\beta}(t) \\
& \frac{I_{\gamma}(t+h)-I_{\gamma}(t)}{h}=b_{2} C_{T}(t)-\mu_{3} I_{\gamma}(t)
\end{aligned}
$$

Sehingga diperoleh hasil diskritisasi sebagai berikut:

$$
\begin{aligned}
& G_{m+1}= G_{m}+h r_{1} G_{m}\left(1-\frac{G_{m}}{G_{\max }}\right)-h\left(\frac{1}{T_{\beta m}+e_{1}}\right)\left(\alpha_{1} M_{m}+\alpha_{2} C_{T}\right)\left(\frac{G_{m}}{G_{m}+k_{1}}\right) \\
& M_{m+1}=M_{m}+ h r_{2} M_{m}\left(1-\frac{M_{m}}{M_{\max }}\right)+h a_{1}\left(\frac{I_{\gamma_{m}}}{k_{4}+I_{\gamma_{m}}}\right)\left(\frac{1}{T_{\beta_{m}}+e_{2}}\right) \\
& \quad-h \alpha_{3}\left(\frac{G_{m}}{G_{m}+k_{2}}\right) M_{m} \\
& C_{T m+1}= C_{m}+h \frac{a_{2} G_{m}}{k_{5}+T_{m}}-h \mu_{1} C_{m}-h \alpha_{4} \frac{G_{m}}{G_{m}+k_{3}} C_{T_{m}} \\
& T_{\beta_{m+1}=}=T_{\beta_{m}}+h s_{1}+h b_{1} G_{m}-h \mu_{2} T_{\beta_{m}} \\
& I_{\gamma_{m+1}=}
\end{aligned}
$$

\section{b. Titik Kesetimbangan Model}

Titik kesetimbangan pada sistem persamaan (3) memenuhi kondisi $G_{m+1}=G_{m}=G^{*}$ dan analogi dengan $M_{m+1}, C_{m+1}, T_{\beta_{m+1}}, I_{\gamma_{m+1}}$ yaitu

$$
\begin{aligned}
& \frac{G^{*}-G^{*}}{h}=r_{1} G^{*}\left(1-\frac{G^{*}}{G_{\max }}\right)-\left(\frac{1}{T_{\beta}^{*}+e_{1}}\right)\left(\alpha_{1} M^{*}+\alpha_{2} C_{T}^{*}\right)\left(\frac{G^{*}}{G^{*}+k_{1}}\right) \\
& \frac{M^{*}-M^{*}}{h}=r_{2} M^{*}\left(1-\frac{M^{*}}{M_{\max }}\right)+a_{1}\left(\frac{I_{\gamma}^{*}}{k_{4}+I_{\gamma}^{*}}\right)\left(\frac{1}{T_{\beta}^{*}+e_{2}}\right)-\alpha_{3}\left(\frac{G^{*}}{G^{*}+k_{2}}\right) M^{*} \\
& \frac{C_{T}^{*}-C_{T}^{*}}{h}=\frac{a_{2} G^{*}}{k_{5}+T_{\beta}^{*}}-\mu_{1} C_{T}^{*}-\alpha_{4} \frac{G^{*}}{G^{*}+k_{3}} C_{T}^{*}
\end{aligned}
$$




$$
\begin{aligned}
& \frac{T_{\beta}^{*}-T_{\beta}^{*}}{h}=s_{1}+b_{1} G^{*}-\mu_{2} T_{\beta}^{*} \\
& \frac{I_{\gamma}^{*}-I_{\gamma}^{*}}{h}=b_{2} C_{T}^{*}-\mu_{3} I_{\gamma}^{*}
\end{aligned}
$$

Sehingga,

$$
\begin{aligned}
& G^{*}\left(r_{1}\left(1-\frac{G^{*}}{G_{\max }}\right)-\left(\frac{1}{T_{\beta}^{*}+e_{1}}\right)\left(\alpha_{1} M^{*}+\alpha_{2} C_{T}^{*}\right)\left(\frac{1}{G^{*}+k_{1}}\right)\right)=0 \\
& r_{2} M^{*}\left(1-\frac{M^{*}}{M_{\max }}\right)+a_{1}\left(\frac{I_{\gamma}^{*}}{k_{4}+I_{\gamma}^{*}}\right)\left(\frac{1}{T_{\beta}^{*}+e_{2}}\right)-\alpha_{3}\left(\frac{G^{*}}{G^{*}+k_{2}}\right) M^{*}=0 \\
& G^{*}\left(\frac{a_{2}}{k_{5}+T_{\beta}^{*}}-\alpha_{4} \frac{1}{1+k_{3}} C_{T}^{*}\right)-\mu_{1} C_{T}^{*}=0 \\
& s_{1}+b_{1} G^{*}-\mu_{2} T_{\beta}^{*}=0 \\
& b_{2} C_{T}^{*}-\mu_{3} I_{\gamma}^{*}=0
\end{aligned}
$$

Berdasarkan persamaan (5) diperoleh dua kemungkinan nilai $G^{*}$, yaitu saat sel glioma tidak ada atau $G^{*}=0$ maka disebut titik kesetimbangan bebas penyakit, dan saat sel glioma ada atau $G^{*} \neq 0$ maka disebut titik kesetimbangan endemik. Titik kesetimbangan bebas penyakit merupakan suatu keadaan di mana tumor otak tidak ada di dalam tubuh atau saat $G^{*}=0$. Titik tetap bebas penyakit dari semua substitusi persamaan dan nilai parameternya menghasilkan $E_{0}=\left(G^{*}, M^{*}, C^{*}, T_{\beta}^{*}, I_{\gamma}^{*}\right)=\left(0,10^{6}, 0,9134,0\right)$. Sedangkan, Titik kesetimbangan endemik adalah suatu kondisi di mana adanya tumor otak dalam tubuh atau saat $G^{*} \neq 0$. titik tetap endemiknya dari semua substitusi persamaan dan nilai parameternya menghasilkan $E_{1}=\left(G^{*}, M^{*}, C^{*}, T_{\beta}^{*}, I_{\gamma}^{*}\right)$

$$
=(875419,943092,302.43,9135,0.302) \text {. }
$$

Setelah diperoleh hasil diskritisasi dengan menggunakan metode beda hingga standar, berdasarkan sistem (3) diperoleh matriks Jacobi sebagai berikut

$$
J_{E}=\left(\begin{array}{c}
\frac{\partial G_{m+1}}{\partial G_{m}} \frac{\partial G_{m+1}}{\partial M_{m}} \frac{\partial G_{m+1}}{\partial C_{m}} \frac{\partial G_{m+1}}{\partial T_{m}} \frac{\partial G_{m+1}}{\partial I_{m}} \\
\frac{\partial M_{m+1}}{\partial G_{m}} \frac{\partial M_{m+1}}{\partial M_{m}} \frac{\partial M_{m+1}}{\partial C_{m}} \frac{\partial M_{m+1}}{\partial T_{m}} \frac{\partial M_{m+1}}{\partial I_{m}} \\
\frac{\partial C_{m+1}}{\partial G_{m}} \frac{\partial C_{m+1}}{\partial M_{m}} \frac{\partial C_{m+1}}{\partial C_{m}} \frac{\partial C_{m+1}}{\partial T_{m}} \frac{\partial C_{m+1}}{\partial I_{m}} \\
\frac{\partial T_{m+1}}{\partial G_{m}} \frac{\partial T_{m+1}}{\partial M_{m}} \frac{\partial T_{m+1}}{\partial C_{m}} \frac{\partial T_{m+1}}{\partial T_{m}} \frac{\partial T_{m+1}}{\partial I_{m}} \\
\frac{\partial I_{m+1}}{\partial G_{m}} \frac{\partial I_{m+1}}{\partial M_{m}} \frac{\partial I_{m+1}}{\partial C_{m}} \frac{\partial I_{m+1}}{\partial T_{m}} \frac{\partial I_{m+1}}{\partial I_{m}}
\end{array}\right)
$$

Titik kesetimbangan bebas penyakit $E_{0}=\left(G^{*}, M^{*}, C^{*}, T_{\beta}^{*}, I_{\gamma}^{*}\right)=\left(0,10^{6}, 0,9134,0\right)$ disubstitusikan ke persamaan (6) menghasilkan matriks Jacobi:

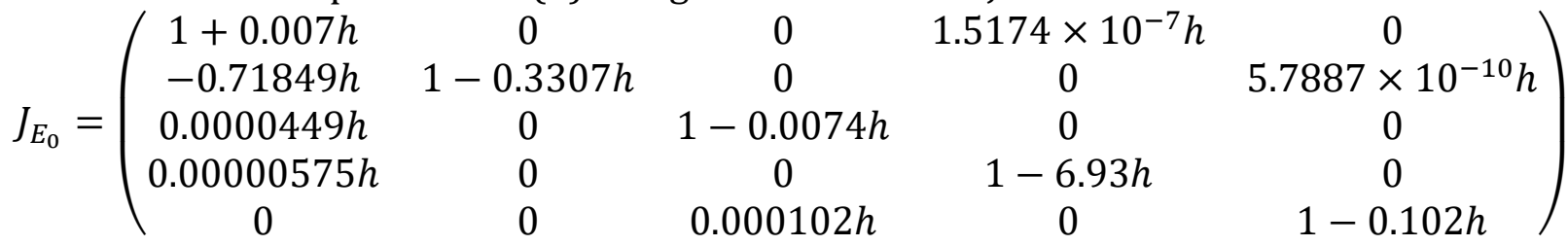

Dari matriks Jacobi tersebut akan ditentukan persamaan karakteristik dan nilai eigennya yang diperoleh $\operatorname{dari} \operatorname{det}\left(\lambda I-J_{E_{0}}\right)=0$. 


$$
\begin{aligned}
& \operatorname{det}\left(\lambda I-J_{E_{0}}\right) \\
& =\left(\begin{array}{ccccc}
\lambda-1-0.007 h & 0 & 0 & 1.5174 \times 10^{-7} h & 0 \\
-0.71849 h & \lambda-1+0.3307 h & 0 & 0 & 5.7887 \times 10^{-10} h \\
0.0000449 h & 0 & \lambda-1+0.0074 h & 0 & 0 \\
0.00000575 h & 0 & 0 & \lambda-1+6.93 h & 0 \\
0 & 0 & 0.000102 h & 0 & \lambda-1+0.102 h
\end{array}\right) \\
& E_{0}(\lambda)=\lambda^{5}+A_{1} \lambda^{4}+A_{2} \lambda^{3}+A_{3} \lambda^{2}+A_{4} \lambda+A_{5}
\end{aligned}
$$

Kestabilan dari titik kesetimbangan bebas penyakit dapat ditentukan dengan kriteria kestabilan Schur-Cohn.

$$
\begin{aligned}
& A(1)=1+A_{1}+A_{2}+A_{3}+A_{4}+A_{5}>0 \\
& =-0.03460152110 h^{4}-0.00001161207658 h^{5}>0 \\
& (-1)^{k} A(-1)=(-1)^{5}\left(-1+A_{1}-A_{2}+A_{3}-A_{4}+A_{5}\right)>0 \\
& =32-119.7326583 h+31.40073619 h^{2}-2.536392336 h^{3} \\
& +0.06885666018 h^{4}+0.000280897565 h^{5}>0 \\
& B_{3}^{ \pm}=\left(\begin{array}{cccc}
1 & 0 & 0 & 0 \\
A_{1} & 1 & 0 & 0 \\
A_{2} & A_{1} & 1 & 0 \\
A_{3} & A_{2} & A_{1} & 1
\end{array}\right) \pm\left(\begin{array}{cccc}
0 & 0 & 0 & A_{5} \\
0 & 0 & A_{5} & A_{4} \\
0 & A_{5} & A_{4} & A_{3} \\
A_{5} & A_{4} & A_{3} & A_{2}
\end{array}\right) \\
& B_{3}^{+}=\left(\begin{array}{cccc}
1 & 0 & 0 & 0 \\
A_{1} & 1 & 0 & 0 \\
A_{2} & A_{1} & 1 & 0 \\
A_{3} & A_{2} & A_{1} & 1
\end{array}\right)+\left(\begin{array}{cccc}
0 & 0 & 0 & A_{5} \\
0 & 0 & A_{5} & A_{4} \\
0 & A_{5} & A_{4} & A_{3} \\
A_{5} & A_{4} & A_{3} & A_{2}
\end{array}\right)
\end{aligned}
$$

$=1.818191257 \times 10^{-20} h^{20}+2.156282327 \times 10^{-16} h^{19}+9.571405114 \times 10^{-13} h^{18}$

$+1.879274989 \times 10^{-9} h^{17}+0.000001357195461 h^{16}$

$-0.00004629759622 h^{15}-122.8657711 h^{7}+39.18761267 h^{6}$

$+16.88451505 h^{10}-68.85946174 h^{9}+0.3131100688 h^{12}$

$-2.712211763 h^{11}+143.3373584 h^{8}+0.001429468307 h^{14}$

$-0.02463536835 h^{13}-4.076088620 h^{5}-0.0000246710089 h^{4}$

$-0.0001249460 h^{3}+0.00000807 h^{2}+0.00000100 h>0$

$$
B_{3}^{-}=\left(\begin{array}{cccc}
1 & 0 & 0 & 0 \\
A_{1} & 1 & 0 & 0 \\
A_{2} & A_{1} & 1 & 0 \\
A_{3} & A_{2} & A_{1} & 1
\end{array}\right)-\left(\begin{array}{cccc}
0 & 0 & 0 & A_{5} \\
0 & 0 & A_{5} & A_{4} \\
0 & A_{5} & A_{4} & A_{3} \\
A_{5} & A_{4} & A_{3} & A_{2}
\end{array}\right)
$$

$=1.818191257 \times 10^{-20} h^{20}+2.15628232710^{-16} h^{19}+9.578704770 \times 10^{-13} h^{18}$

$+1.885739273 \times 10^{-9} h^{17}+0.000001376148419 h^{16}$

$-0.00002828201878 h^{15}+0.00000121174 h^{7}-0.000004413463 h^{6}$

$-1.199048788 h^{10}+2.281720359 h^{9}-0.009828657502 h^{12}$

$+0.1678399491 h^{11}-0.001199402709 h^{8}+0.0003159451827 h^{14}$

$-0.001204115237 h^{13}+0.000002396 h^{5}-0.00005431 h^{4}+0.0000958 h^{3}$

$-0.000024 h^{2}-0.0000020 h>0$ 
Titik kesetimbangan endemik

$$
E_{1}=\left(G^{*}, M^{*}, C^{*}, T_{\beta}^{*}, I_{\gamma}^{*}\right)=(875419,943092,302.43,9135,0.302)
$$

disubstitusikan ke persamaan (6) menghasilkan matriks Jacobi:

$$
\begin{aligned}
& J_{E_{1}} \\
& =\left(\begin{array}{ccccc}
1-0.0098 h & -0.000076 h & -0.00000061 h & 4.28 \times 10^{-9} h & 0 \\
-0.020274 h & 1-0.31188 h & 0 & 9.135 \times 10^{-15} h & 5.788 \times 10^{-10} h \\
0.000033 h & 0 & 1-0.12957 h & -0.00353025 h & 0 \\
0.0000057 h & 0 & 0 & 1-6.93 h & 0 \\
0 & 0 & 0.000102 h & 0 & 1-0.102 h
\end{array}\right)
\end{aligned}
$$

Dari matriks Jacobi tersebut akan ditentukan persamaan karakteristik dan nilai eigennya yang diperoleh $\operatorname{dari} \operatorname{det}\left(\lambda I-J_{E_{1}}\right)=0$.

$$
\begin{aligned}
& \operatorname{det}\left(\lambda I-J_{E_{1}}\right) \\
& =\left(\begin{array}{ccccc}
\lambda-1+0.0098 h & -0.000076 h & -0.00000061 h & 4.28 \times 10^{-9} h & 0 \\
-0.020274 h & \lambda-1+0.31188 h & 0 & 9.135 \times 10^{-15} h & 5.788 \times 10^{-10} h \\
0.000033 h & 0 & \lambda-1+0.12957 h & -0.00353025 h & 0 \\
0.0000057 h & 0 & 0 & \lambda-1+6.93 h & 0 \\
0 & 0 & 0.000102 h & 0 & \lambda-1+0.102 h
\end{array}\right)
\end{aligned}
$$

Persamaan karakteristik dari matriks tersebut berupa polinom berderajat lima yaitu dengan

$$
E_{1}(\lambda)=\lambda^{5}+A_{1} \lambda^{4}+A_{2} \lambda^{3}+A_{3} \lambda^{2}+A_{4} \lambda+A_{5}
$$

$A_{1}=7.483291143 h-5$

$A_{2}=3.925092024 h^{2}-29.93316457 h+10$

$A_{3}=0.63409880842 h^{3}-11.77527607 h^{2}+44.89974686 h-10$

$A_{4}=0.03442833009 h^{4}-1.268196168 h^{3}+11.77527607 h^{2}-29.93316457 h+5$

$A_{5}=0.0002808975658 h^{5}-0.03442833009 h^{4}+0.6340980842 h^{3}-3.925092024 h^{2}$

$$
+7.483291143 h-1
$$

Kestabilan dari titik kesetimbangan endemik dapat ditentukan dengan kriteria kestabilan Schur-Cohn. Solusi persamaan (3.2) dikatakan stabil asimtotik jika memenuhi tiga syarat, yaitu

$$
\begin{gathered}
A(1)=1+A_{1}+A_{2}+A_{3}+A_{4}+A_{5}>0 \\
=1 \times 10^{-8}+0.0002808975658 h^{5}>0 \\
(-1)^{k} A(-1)=(-1)^{5}\left(-1+A_{1}-A_{2}+A_{3}-A_{4}+A_{5}\right)>0 \\
=32-119.7326583 h+31.40073619 h^{2}-2.536392336 h^{3}+0.06885666018 h^{4} \\
-0.0002808975658 h^{5}>0 \\
B_{3}^{ \pm}=\left(\begin{array}{cccc}
1 & 0 & 0 & 0 \\
A_{1} & 1 & 0 & 0 \\
A_{2} & A_{1} & 1 & 0 \\
A_{3} & A_{2} & A_{1} & 1
\end{array}\right) \pm\left(\begin{array}{cccc}
0 & 0 & 0 & A_{5} \\
0 & 0 & A_{5} & A_{4} \\
0 & A_{5} & A_{4} & A_{3} \\
A_{5} & A_{4} & A_{3} & A_{2}
\end{array}\right) \\
B_{3}^{+}=\left(\begin{array}{cccc}
1 & 0 & 0 & 0 \\
A_{1} & 1 & 0 & 0 \\
A_{2} & A_{1} & 1 & 0 \\
A_{3} & A_{2} & A_{1} & 1
\end{array}\right)+\left(\begin{array}{cccc}
0 & 0 & 0 & A_{5} \\
0 & 0 & A_{5} & A_{4} \\
0 & A_{5} & A_{4} & A_{3} \\
A_{5} & A_{4} & A_{3} & A_{2}
\end{array}\right) \\
-3.052248413 \times 10^{-12} h^{19}-0.0002291150193 h^{15} \\
+6.314202630 \times 10^{-10} h^{18}-7.22987490410^{-8} h^{17} \\
+0.000005072415816 h^{16}-1178.216562 h^{7}+260.7545659 h^{6} \\
+113.8627974 h^{10}-458.8797575 h^{9}+1.914413679 h^{12}-18.05189622 h^{11} \\
+1075.212571 h^{8}+0.006851372909 h^{14}-0.1385090193 h^{13} \\
+ \\
+
\end{gathered}
$$


$\left(\begin{array}{llll}A_{3} & A_{2} & A_{1} & 1\end{array}\right)\left(\begin{array}{cccc}A_{5} & A_{4} & A_{3} & A_{2}\end{array}\right)$

$$
B_{3}^{-}=\left(\begin{array}{cccc}
1 & 0 & 0 & 0 \\
A_{1} & 1 & 0 & 0 \\
A_{2} & A_{1} & 1 & 0 \\
A_{3} & A_{2} & A_{1} & 1
\end{array}\right)-\left(\begin{array}{cccc}
0 & 0 & 0 & A_{5} \\
0 & 0 & A_{5} & A_{4} \\
0 & A_{5} & A_{4} & A_{3} \\
A_{5} & A_{4} & A_{3} & A_{2}
\end{array}\right)
$$

$=-0.0001077851867 h^{15}+6.033122358 \times 10^{-10} h^{18}-6.144156264 \times 10^{-8} h^{17}$

$+0.00003442399294 h^{16}+6.22575323 \times 10^{-15} h^{20}-3.052248413 \times 10^{-12} h h^{19}$

$+0.001959149698 h^{14}-0.02100674718 h^{13}+7.9778 \times 10^{-7} h^{7}+0.000009531 h^{6}$

$+0.5294706622 h^{10}-1.666354 \times 10^{-8} h^{9}+0.1295704720 h^{12}-0.417808219 h^{11}$

$-0.000002820160 h^{8}+0.00009480 h^{5}+0.00036622991 h^{4}-0.0000026032 h^{3}$

$+0.0 .00002121 h^{2}+7.2 \times 10^{-7} h$

$>$ 0di mana86di mana86di mana86di mana86di mana86di mana86di mana86di mana86di mana86di ma

\section{Simulasi dan interpretasi grafik}

Setelah mendiskritisasi dan menganalisis kestabilan model matematika penyebaran tumor otak dengan respons sistem imun, selanjutnya hasil diskritisasi atau model diskrit tersebut disimulasikan dengan menyubstitusikan parameter di bawah ini:

Tabel 1. Tabel nilai parameter model penyebaran tumor otak dengan respons sistem imun

\begin{tabular}{|c|c|c|c|c|}
\hline No & Parameter & $\begin{array}{r}\text { Deskripsi } \\
\text { Parameter }\end{array}$ & $\begin{array}{r}\text { Nilai } \\
\text { Parameter } \\
\end{array}$ & Satuan \\
\hline 1. & $r_{1}$ & $\begin{array}{l}\text { Laju } \\
\text { pertumbuhan } \\
\text { glioma }\end{array}$ & 0.01 & $h^{-1}$ \\
\hline 2. & $G_{\max }$ & $\begin{array}{c}\text { Carrying } \\
\text { capacity sel glioma }\end{array}$ & $8.8265 \times 10^{5}$ & sel \\
\hline 3. & $e_{1}$ & $\begin{array}{r}\text { Konstanta } \\
\text { Michaelis Menten } \\
\end{array}$ & $10^{4}$ & $p g$ \\
\hline 4. & $\alpha_{1}$ & $\begin{array}{c}\text { Laju } \\
\text { pembunuhan glioma } \\
\text { oleh makrofag }\end{array}$ & 1.5 & $p g \cdot h^{-1}$ \\
\hline 5. & $\alpha_{2}$ & \begin{tabular}{l}
\multicolumn{1}{c}{ Laju } \\
pembunuhan glioma \\
oleh sel T CD8+
\end{tabular} & 0.12 & $p g \cdot h^{-1}$ \\
\hline 6. & $k_{1}$ & $\begin{array}{r}\text { Konstanta } \\
\text { setengah saturasi }\end{array}$ & $2.7 \times 10^{4}$ & sel \\
\hline 7. & $r_{2}$ & $\begin{array}{l}\quad \text { Laju } \\
\text { pertumbuhan } \\
\text { makrofag }\end{array}$ & 0.3307 & $h^{-1}$ \\
\hline 8. & $M_{\max }$ & $\begin{array}{c}\text { Carrying } \\
\text { capacity makrofag }\end{array}$ & $10^{6}$ & sel \\
\hline 9. & $a_{1}$ & $\begin{array}{l}\text { Laju aktivasi } \\
\text { makrofag }\end{array}$ & 0.1163 & sel. $h^{-1}$ \\
\hline 10. & $k_{4}$ & $\begin{array}{r}\text { Konstanta } \\
\text { setengah saturasi } \\
\end{array}$ & $1.05 \times 10^{4}$ & sel \\
\hline 11. & $e_{2}$ & $\begin{array}{r}\text { Konstanta } \\
\text { Michaelis Menten }\end{array}$ & $10^{4}$ & $p g$ \\
\hline 12. & $\alpha_{3}$ & $\begin{array}{l}\text { Laju kematian } \\
\text { makrofag }\end{array}$ & 0.0194 & $h^{-1}$ \\
\hline
\end{tabular}




\begin{tabular}{|c|c|c|c|c|}
\hline 13. & $k_{2}$ & $\begin{array}{r}\text { Konstanta } \\
\text { setengah saturasi }\end{array}$ & $2.7 \times 10^{4}$ & sel \\
\hline 14. & $a_{2}$ & Antigen glioma & 0.5 & $h \cdot p g^{-1}$ \\
\hline 15. & $k_{5}$ & $\begin{array}{l}\text { Parameter } \\
\text { inhibitor }\end{array}$ & $2 \times 10^{3}$ & $p g$ \\
\hline 16. & $\mu_{1}$ & $\begin{array}{l}\text { Kematian alami } \\
\text { sel T CD8+ }\end{array}$ & 0.0074 & $h^{-1}$ \\
\hline 17. & $\alpha_{4}$ & $\begin{array}{l}\text { Laju kematian } \\
\text { sel T CD8+ }\end{array}$ & 0.1694 & $h^{-1}$ \\
\hline 18. & $k_{3}$ & $\begin{array}{r}\text { Konstanta } \\
\text { setengah saturasi } \\
\end{array}$ & $\begin{array}{l}3.34452 \\
\times 10^{5} \\
\end{array}$ & sel \\
\hline 19. & $s_{1}$ & $\begin{array}{c}\text { Konstanta } \\
\text { sumber sitoksin TGF- } \beta\end{array}$ & $6.3305 \times 10^{4}$ & $p g \cdot h^{-1}$ \\
\hline 20. & $b_{1}$ & $\begin{array}{l}\text { Laju kelahiran } \\
\text { TGF- } \beta \text { setiap glioma }\end{array}$ & $5.70 \times 10^{-6}$ & $p g \cdot \operatorname{sel}^{-1} \cdot h^{-1}$ \\
\hline 21. & $\mu_{2}$ & $\begin{array}{l}\text { Kematian alami } \\
\text { sitoksin TGF- } \beta\end{array}$ & 6.93 & $h^{-1}$ \\
\hline 22. & $b_{2}$ & $\begin{array}{l}\text { Laju pelepasan } \\
\text { setiap sel T CD8+ }\end{array}$ & $1.02 \times 10^{-4}$ & $p g \cdot \operatorname{sel}^{-1} \cdot h^{-1}$ \\
\hline 23. & $\mu_{3}$ & $\begin{array}{l}\text { Penurunan } \\
\text { sitoksin IFN- } \gamma\end{array}$ & $0.102 h^{-1}$ & $h^{-1}$ \\
\hline
\end{tabular}

\section{a. Simulasi Syarat Kestabilan}
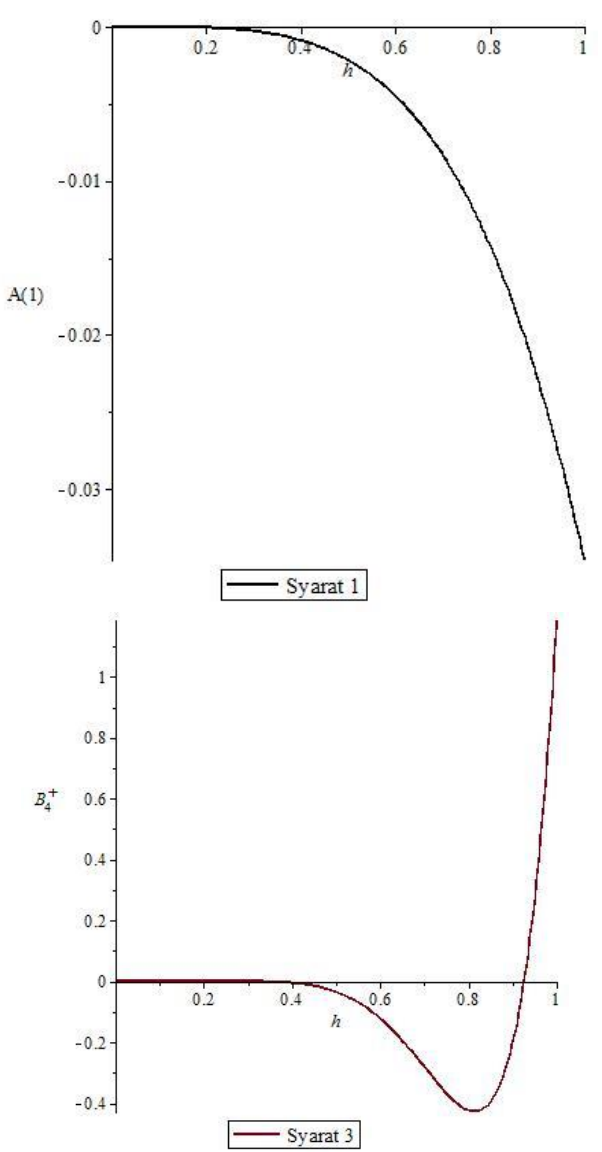
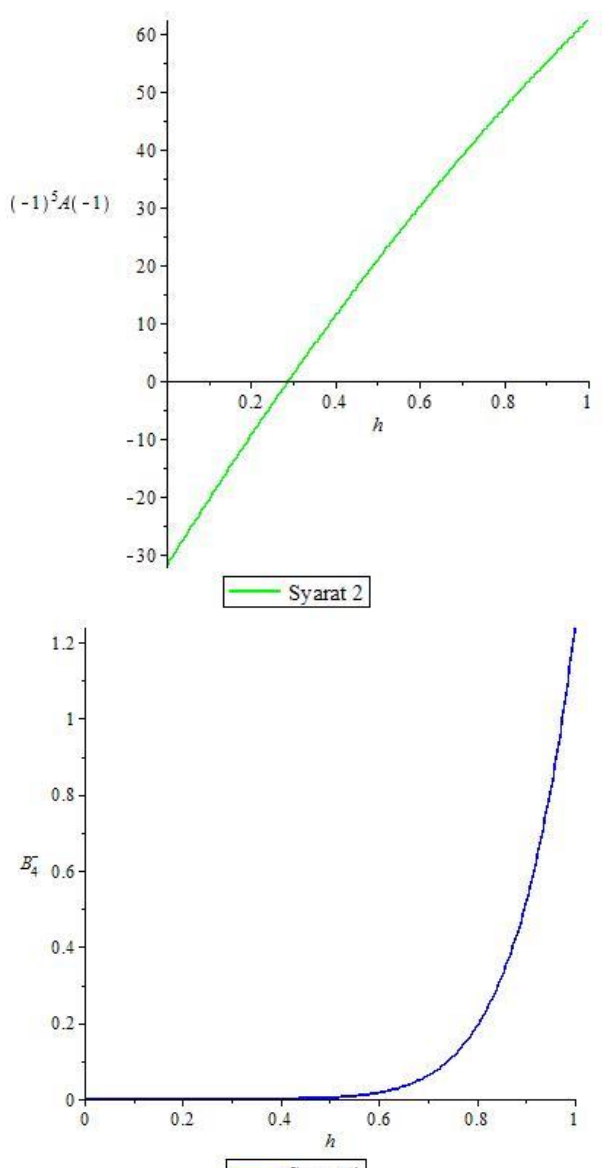

Gambar 1 Grafik Daerah Penyelesaian Bebas Penyakit 
Grafik di atas merupakan daerah penyelesaian dari kestabilan bebas penyakit yang diperoleh dari kriteria Schur-Cohn yang berbentuk sistem pertidaksamaan. Berdasarkan grafik tersebut didapatkan bahwa sistem persamaan pada model penyebaran tumor otak dengan respons sistem imun tidak stabil saat bebas penyakit. Hal tersebut karena ada satu syarat yang tidak terpenuhi, yaitu syarat pertama pada kriteria kestabilan Schur-Cohn menunjukkan bahwa $h<0$.
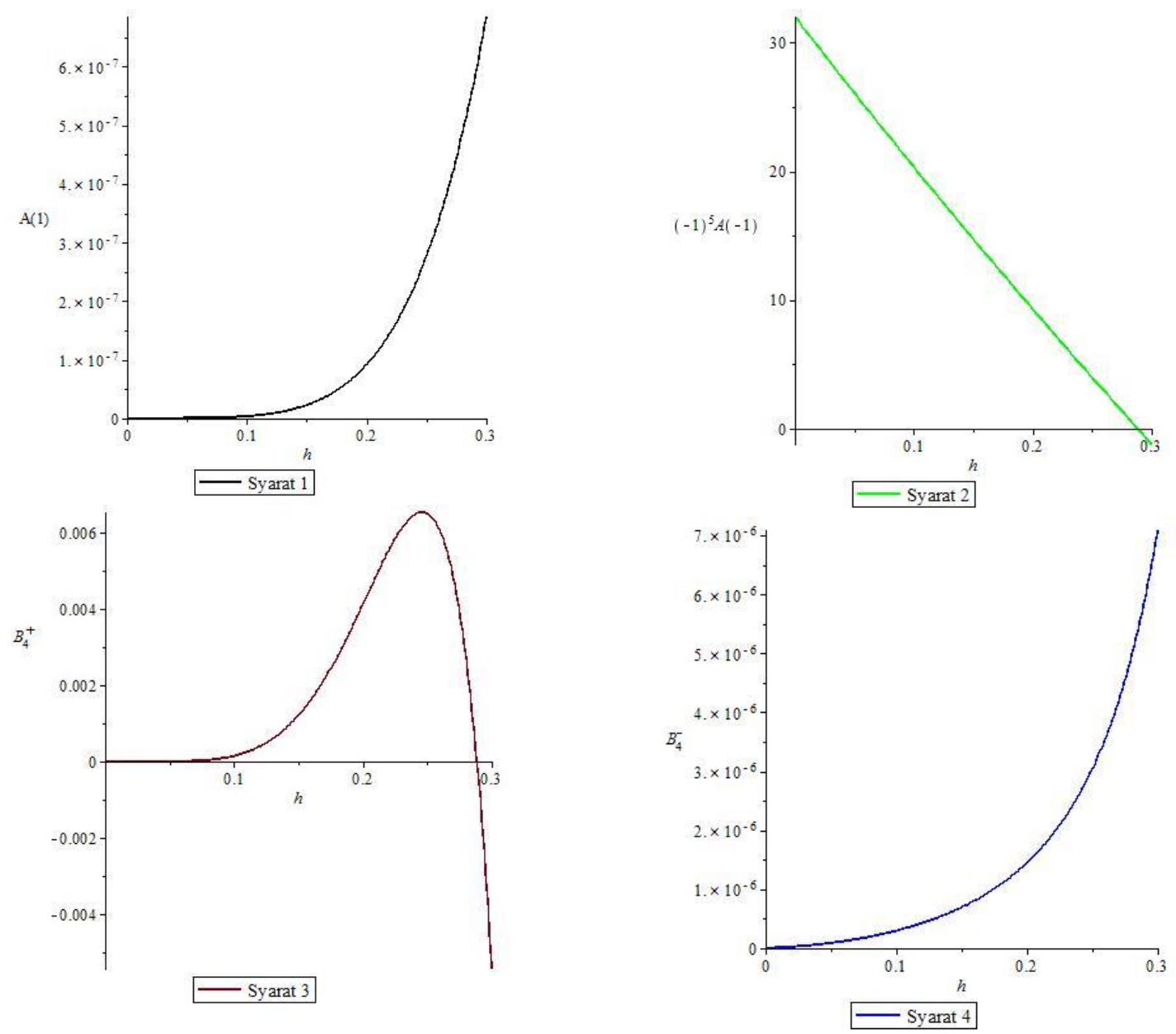

Gambar 2 Grafik Daerah Penyelesaian Endemik

Grafik di atas merupakan daerah penyelesaian dari kestabilan endemik yang diperoleh dari kriteria Schur-Cohn yang berbentuk sistem pertidaksamaan. Syarat pertama ditunjukkan oleh garis berwarna hitam dengan daerah penyelesaian saat $h>0$. Syarat kedua ditunjukkan oleh garis berwarna bijau dengan derah penyelesaian saat $0<h \leq$ 0.28 . Syarat ketiga ditunjukkan oleh garis berwarna merah dengan daerah penyelesaian saat $0<h \leq 0.28$. Selanjutnya, syarat terakhir ditunjukkan oleh garis berwarna biru dengan daerah penyelesaian saat $0<h \leq 3.34$. Sehingga, model diskrit penyebaran tumor otak dengan respon sistem imun stabil pada kesetimbangan endemik saat $0<h \leq 0.28$.

\section{b. Simulasi Model Diskrit}



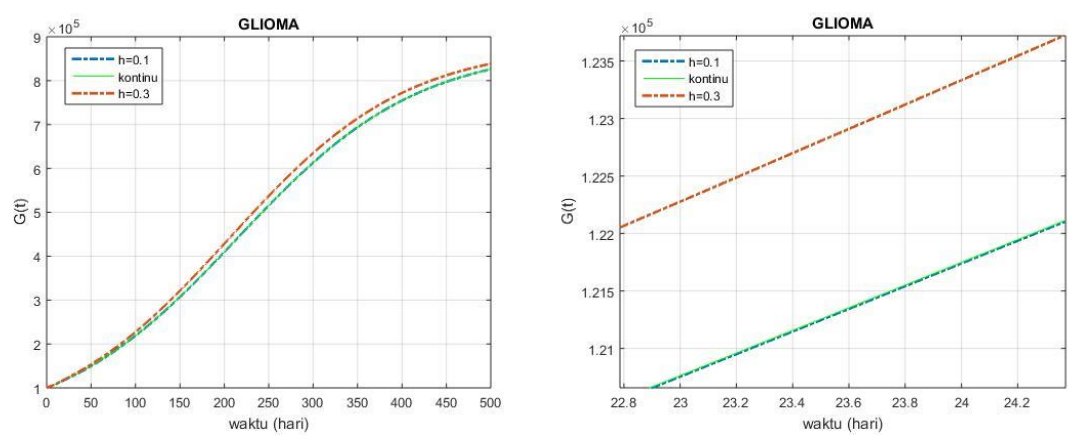

Gambar 3 Grafik Sel Glioma dengan $\mathrm{h}=0.1$ dan 0.3
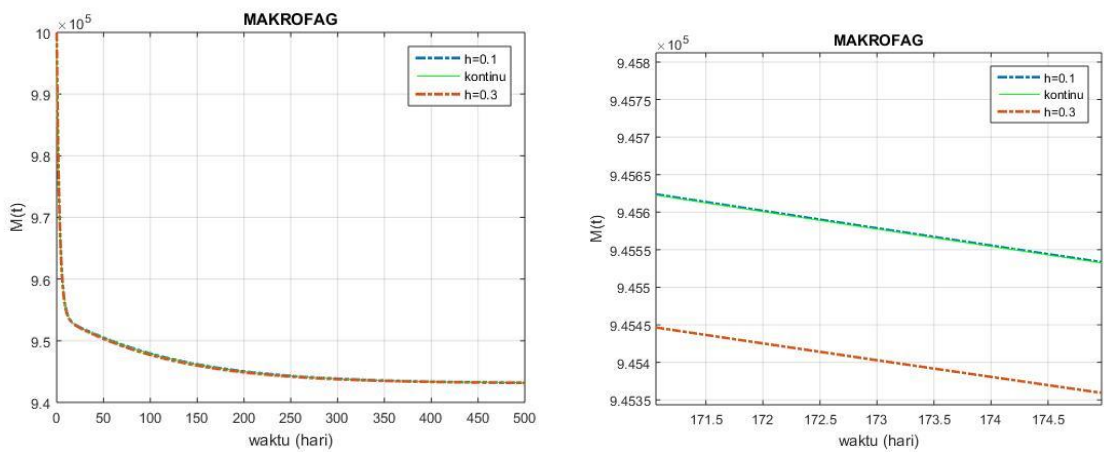

Gambar 4 Grafik Makrofag dengan $\mathrm{h}=0.1$ dan 0.3
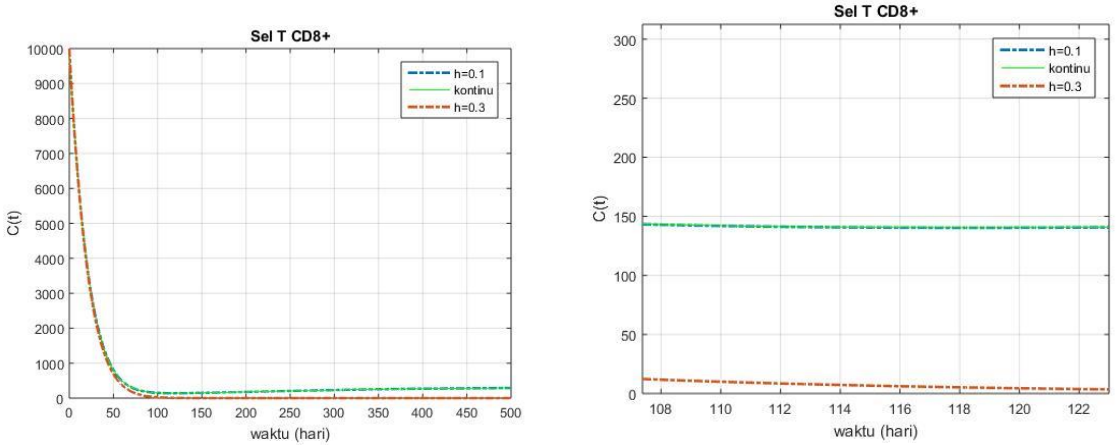

Gambar 5 Grafik Sel T CD8 ${ }^{+}$dengan $\mathrm{h}=0.1$ dan 0.3
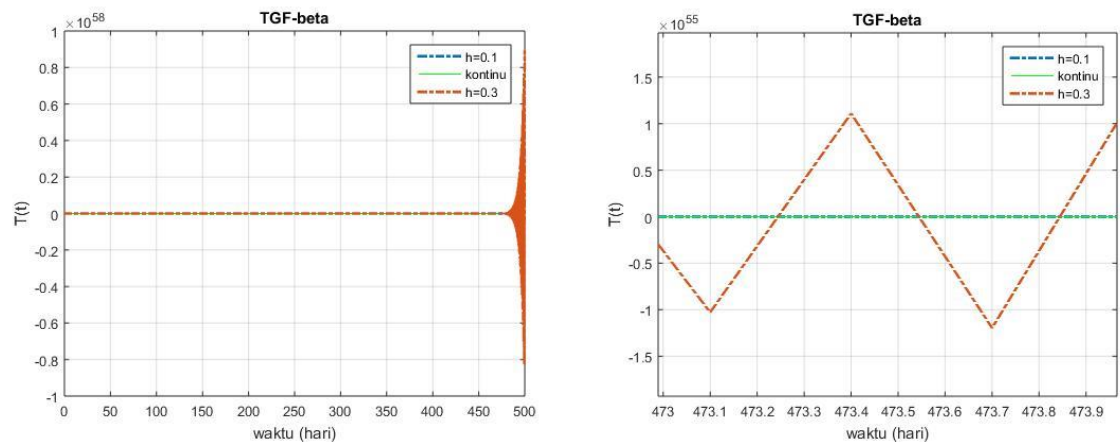

Gambar 6 Grafik TGF- $\beta$ dengan $\mathrm{h}=0.1$ dan 0.3 

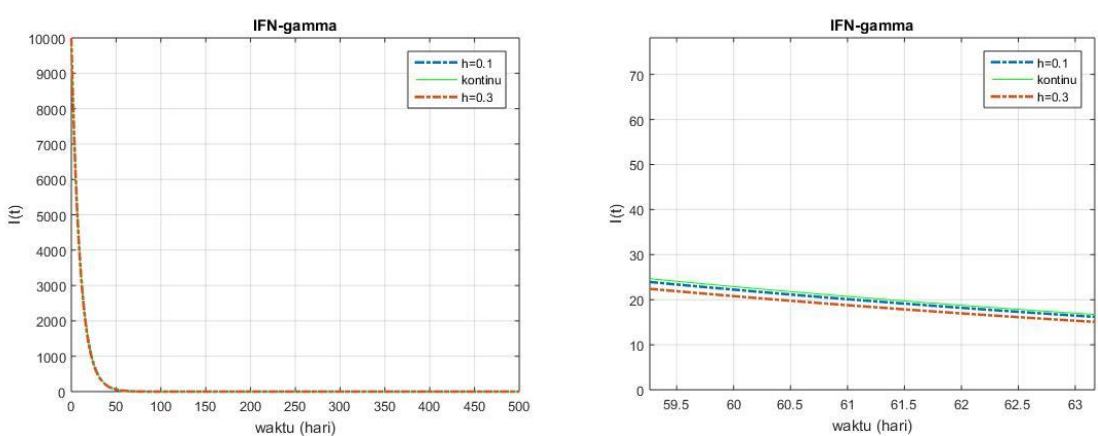

Gambar 7 Grafik IFN- $\gamma$ dengan $h=0.1$ dan 0.3

Grafik di atas merupakan simulasi model diskrit penyebaran tumor otak dengan respons sistem imun. Berdasarkan grafik tersebut terlihat bahwa saat $h=0.1$ grafik diskritnya akan berhimpit atau sama dengan grafik kontinunya. Sedangkan, saat $h=0.3$ grafik akan menjauhi grafik kontinunya bahkan tidak stabil. Sehingga, terbukti bahwa saat $h \leq 0.35$ maka grafik akan tidak stabil atau menjauhi grafik asalnya. Saat $0<h \leq 0.34$ grafik akan stabil atau sama dengan grafik kontinunya.

\section{c. Simulasi dengan Mengubah Nilai Parameter}

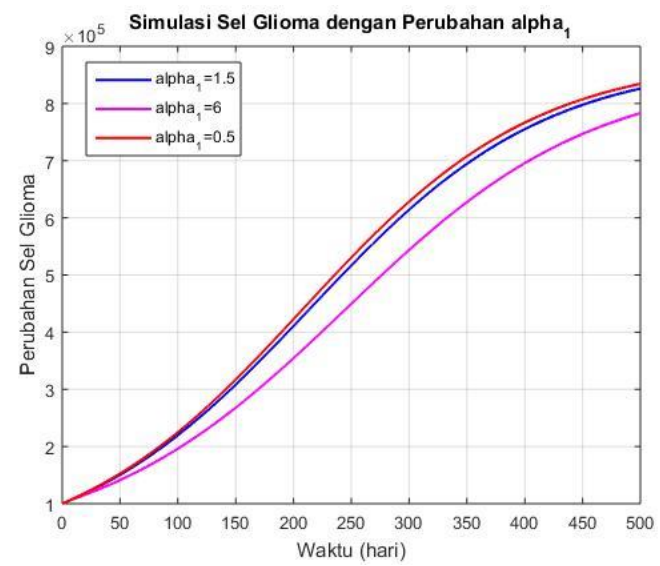

Gambar 8 Grafik Simulasi Sel Glioma dengan Perubahan Parameter $\alpha_{1}=1.5, \alpha_{1}=6$ dan

$$
\alpha_{1}=0.5
$$

Grafik tersebut merupakan simulasi dengan mengubah parameter $\alpha_{1}$ dengan tiga nilai yang berbeda. Nilai parameter $\alpha_{1}=1,5$ ditunjukkan oleh garis berwarna biru yang mana nilai parameter tersebut asli atau merujuk pada jurnal Banerjee (2015). Nilai parameter $\alpha_{1}$ kemudian diubah dengan $\alpha_{1}=6$ yang ditunjukkan oleh garis berwarna ungu dan $\alpha_{1}=0.5$ yang ditunjukkan oleh garis berwarna merah. Pada grafik di atas terlihat bahwa jumlah populasi glioma menurun saat nilai parameter naik dan meningkat saat nilai parameter turun. 


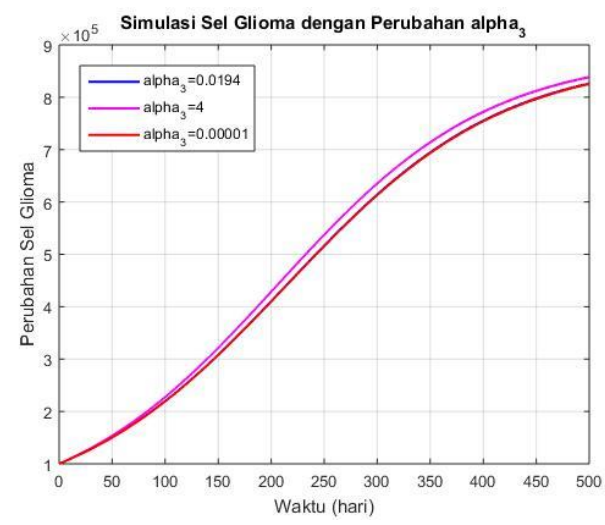

Gambar 9 Grafik Simulasi Sel Glioma dengan Perubahan Parameter $\alpha_{3}=0.0194, \alpha_{3}=4$ dan $\alpha_{3}=0.00001$

Grafik tersebut merupakan simulasi dengan mengubah parameter $\alpha_{3}$ dengan tiga nilai yang berbeda. Nilai parameter $\alpha_{1}=0.0194$ ditunjukkan oleh garis berwarna biru yang mana nilai parameter tersebut asli atau merujuk pada jurnal Banerjee (2015). Nilai parameter $\alpha_{3}$ kemudian diubah dengan $\alpha_{3}=4$ yang ditunjukkan oleh garis berwarna ungu dan $\alpha_{3}=0.00001$ yang ditunjukkan oleh garis berwarna merah. Pada grafik di atas terlihat bahwa jumlah populasi glioma meningkat saat nilai parameter naik dan sama dengan garis biru atau nilai parameter aslinya saat nilai parameternya turun.

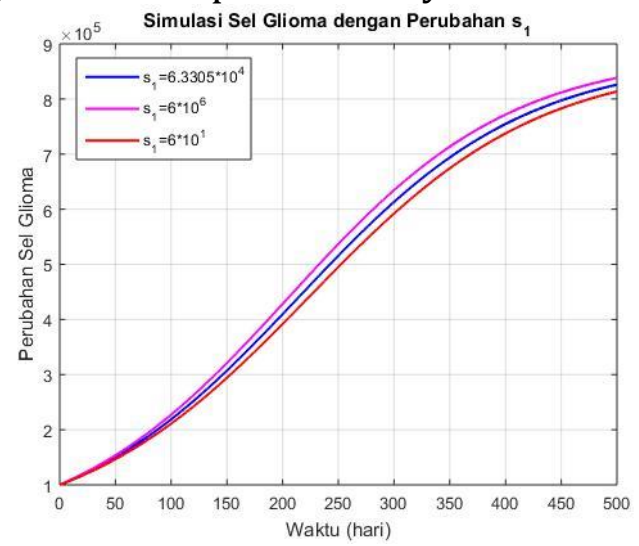

Gambar 10 Grafik Simulasi Sel Glioma dengan Perubahan Parameter $s_{1}=6.3305 \times$

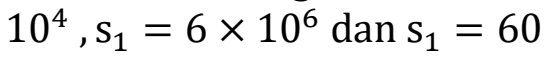

Grafik tersebut merupakan simulasi dengan mengubah parameter $s_{1}$ dengan tiga nilai yang berbeda. Nilai parameter $s_{1}=6,3305 \times 10^{4}$ ditunjukkan oleh garis berwarna biru yang mana nilai parameter tersebut asli atau merujuk pada jurnal Banerjee (2015). Nilai parameter $s_{1}$ kemudian diubah dengan $s_{1}=6 \times 10^{6}$ yang ditunjukkan oleh garis berwarna ungu dan $s_{1}=6 \times 10^{1}$ yang ditunjukkan oleh garis berwarna merah. Pada grafik di atas terlihat bahwa jumlah populasi glioma menurun saat nilai parameter turun dan meningkat saat nilai parameter naik.

\section{KESIMPULAN}

Berdasarkan penelitian di atas dapat disimpulkan bahwa bentuk model diskrit penyebaran tumor otak dengan respons sistem imun adalah pada persamaan (3). Simulasi model diskrit penyebaran tumor otak dengan respons sistem imun menggunakan metode beda hingga pada kesetimbangan bebas penyakit tidak stabil, sedangkan pada kesetimbangan endemik menunjukkan bahwa saat $0<h \leq 0.28$ grafik diskrit berhimpit 
atau sama dengan grafik kontinu model. Selain itu, nilai parameter yang mempengaruhi jumlah populasi sel glioma adalah $\alpha_{1}, \alpha_{3}$ dan $s_{1}$.

\section{DAFTAR PUSTAKA}

[1] World Health Organization (WHO), "Definisi Sehat," 2008.

[2] Pebriana, Kiki Dwi \& Astuti, Luh Gede, "Penerapan Metode Certainty Factor (CF) dalam Pembuatan Sistem Pakar Diagnosis Penyakit Tumor Otak," Jurnal Elektronik Ilmu Komputer Udayana, vol. 8, pp. 315-324, 2020.

[3] Yueniwati, Y, Pencitraan pada Tumor Otak:Modalitas dan Interpretasinya, Malang: UB Press, 2017.

[4] Cumsille, P; Coronel, A; Conca, C, "A note on the numerical approach for the reaction diffusion problem to model the density of the tumor growth dynamics," Computers and Mathematics with Application, 2015.

[5] Enderling, H; Chaplain, M, "Mathematical Modelling of Tumor Growth and Treatment," Current Pharmaceutical Design, 2013.

[6] S. L. Ross, Differential Equation, Delhi: Rajv Book Binding House, 2010.

[7] Nagle; Saff; Snider, Fundamental of Differential Equation, United States of America: Pearson Education, 2018.

[8] El-Nadi, Khairina El-Said; dkk, "Mathematical Model of Brain Tumor," International Research Journal of Engineering and Technology (IRJET) , vol. 2, 2015.

[9] Iaroz, Kelly C; dkk, "Mathematical model of brain tumor with glial-neuron interactions and chemotherapy treatment," Journal of Theoritical Biology, 2015.

[10] Banerjee, S; Khajanchi, S; Chaudhuri, S, "A Mathematical Model to Elucidate Brain Tumor Abrogation by Immunotherapy with T11 Target Structure," Plos One, 2015.

[11] Suryanto, A, Persamaan Diferensial Parsial Numerik II, Malang: Jurusan Matematika Universitas Brawijaya, 2012.

[12] Elaydi, Saber, An Introduction to Difference Equation, New York: Springer, 2015.

[13] Rozi, Syamsida, Metode Numerik, Jambi: Sekolah Tinggi Ilmu Komputer Dinamika Bangsa, 2017.

[14] Liu; Hussein, F; Tan, C, L; Dash, M, Discretization: An Enabling Technique, Arizona: Departement of Computer Science and Enginering-Arizona State University, 2012.

[15] Meyer, Walter J, Concept of Mathematical Modelling, New York: McGraw-Hill Bock Company, 1985. 